\title{
The Massachusetts Health Plan Much Pain, Little Gain
}

by Aaron Yelowitz and Michael F. Cannon

\section{Executive Summary}

In 2006, Massachusetts enacted a sweeping health insurance law that mirrors the legislation currently before Congress. After signing the measure, Gov. Mitt Romney (R) wrote, "Every uninsured citizen in Massachusetts will soon have affordable health insurance and the costs of health care will be reduced." But did the legislation achieve these goals? And what other effects has it had? This paper is the first to use Current Population Survey data for 2008 to evaluate the Massachusetts law, and the first to examine its effects on the accuracy of the CPS's uninsured estimates, self-reported health, the extent of "crowd-out" of private insurance for both children and adults, and in-migration of new Massachusetts residents.

We find evidence that Massachusetts' individual mandate induces uninsured residents to conceal their true insurance status. Even setting that source of bias aside, we find the official estimate reported by the Commonwealth almost certain- ly overstates the law's impact on insurance coverage, likely by 45 percent. In contrast to previous studies, we find evidence of substantial crowdout of private coverage among low-income adults and children. The law appears to have compressed self-reported health outcomes, without necessarily improving overall health. Our results suggest that more than 60 percent fewer young adults are relocating to Massachusetts as a result of the law. Finally, we conclude that leading estimates understate the law's cost by at least one third, and likely more.

Our results hold important lessons for the legislation moving through Congress. As in Massachusetts, there has been no effort to estimate the cost of the private health insurance mandates that legislation would impose on individuals and employers. The costs may therefore be far greater than legislators and voters believe, while the benefits may be smaller than the conventional wisdom about Massachusetts suggests.

Aaron Yelowitz is an associate professor of economics at the University of Kentucky and an adjunct scholar at the Cato Institute. Michael F. Cannon is director of health policy studies at the Cato Institute and coauthor of Healthy Competition: What's Holding Back Health Care and How to Free It. 


\author{
Our study \\ is the first to \\ use Current \\ Population \\ Survey data from \\ 2008 to examine \\ Chapter 58.
}

\section{Introduction}

In 2006, Massachusetts enacted a sweeping health insurance law known as Chapter 58. ${ }^{1}$ The law created the nation's first "individual mandate" to purchase health insurance. All residents whom the Commonwealth deems able to afford health insurance must purchase it or else pay a tax penalty that rises with income. The individual mandate took effect on July 1, 2007, but penalties for noncompliance did not begin until December 31, 2007. Noncompliant residents faced the loss of their personal exemption to the state's income taxa penalty of $\$ 219$. The penalty rose the next year to a maximum of $\$ 912-$ more than four times the 2007 penalty. Each year after 2008, penalties increase at the rate of health insurance premium growth. ${ }^{2}$

Chapter 58 also established the nation's second "employer mandate" (behind Hawaii). Beginning July 1, 2007, the law required firms with 11 or more workers to offer health benefits to their workers and to "contribute" a specified amount toward the cost of that coverage or face a tax penalty of $\$ 295$ per worker. ${ }^{3}$

The law created or expanded various government subsidies to help residents obtain health insurance. It expanded eligibility for Massachusetts' Medicaid program (MassHealth) to children in families with incomes up to 300 percent of the federal poverty level (about $\$ 66,000$ for a family of four); and to adults who are unemployed (100 percent FPL), HIV-positive (200 percent FPL), or disabled. The law created a new CommCare program to provide subsidies for private health insurance to families earning up to 300 percent of the federal poverty level.

Chapter 58 also imposed new rules for private health insurance markets, merged the individual and small-group markets, and created a new health insurance "connector" where individuals and employees of small firms (with 50 or fewer employees) may choose from a variety of health plans.

After signing Chapter 58 into law, Gov. Mitt Romney (R) wrote, "Every uninsured cit- izen in Massachusetts will soon have affordable health insurance and the costs of health care will be reduced." ${ }^{4}$ Changes in Massachusetts' uninsurance rate and health care costs are therefore important measures of the law's impact. Other important indicators of the law's success include its impacts on overall health; "crowd-out" of private health insurance (that is, what percentage of insured people simply switched from private insurance to government-supported insurance); and the attractiveness of Massachusetts as a place to live.

How well Chapter 58 performs on these dimensions has particular relevance now that the federal government is considering similar legislation. When President Barack Obama told Congress in early September 2009, "there is agreement in this chamber on about 80 percent of what needs to be done," he was speaking of the provisions in federal legislation that mirror the Massachusetts law: individual and employer mandates; private health insurance subsidies; Medicaid expansions; a new health insurance "exchange"; and other private health insurance regulations.

This study uses data from the March 2006-2009 supplements to the Current Population Survey-which cover the 2005-2008 calendar years-to measure Chapter 58's impact on some of the above-mentioned factors. Our study is the first to use CPS data from 2008 to examine coverage and crowd-out. It is also the first to use CPS data to examine Chapter 58's impacts on self-reported health and in-migration, and the first to explore whether Chapter 58 introduced bias into the CPS's coverage estimates in Massachusetts. We consider this study to be a first approximation of the effects of Chapter 58 through 2008, and hope that further studies will refine and augment our results.

\section{Methods}

To evaluate the impact of the Massachusetts health law on coverage levels, crowd- 
out, health status, and in-migration patterns, we rely on CPS data from 2005 through 2008. The March supplement to the Census Bureau's CPS has been described as "the survey of record" and "the most viable estimate" of the uninsured. ${ }^{6}$ The Bureau of the Census administers the CPS for the Bureau of Labor Statistics, which scientifically selects the sample to represent the civilian noninstitutional population. The CPS is the official source for national health insurance estimates like the widely cited estimate of 46 million uninsured U.S. residents. The CPS has asked about health insurance since the 1980s, and those questions have been largely unchanged since $1994 .^{7}$ The response rate for the March supplement is exceptionally high compared to other voluntary household-based surveys. The nonresponse rate for the health insurance questions in Massachusetts in 2008 was 16 percent. Nonresponse rates for other surveys measuring the effects of Chapter 58 have been as high as 55 percent $^{8}$ and 68 percent. $^{9}$ Unlike those surveys, the Census Bureau includes residences without telephones by virtue of conducting interviews both by telephone and in person. The CPS data are publicly available from the Census Bureau. ${ }^{10}$ To our knowledge, ours is the first study to employ data from the March 2009 supplement to the CPS, which covers all of calendar year 2008, and the first to examine Massachusetts two years prior to the mandate (2005-2006) and two years after the mandate (2007-2008).

Considerable difficulties arise when we try to measure the impact of a complex piece of legislation such as Chapter 58. For example, the outcomes of interest may be influenced by other changes occurring at the same time. The fact that the various elements of Chapter 58 took effect at different times may further complicate the picture.

Similar to Long et. al., ${ }^{11}$ we employ a difference-in-differences model to control for many factors that might also influence the outcomes of interest. We compare outcomes in Massachusetts to those of other New England states: Maine, New Hampshire, Vermont, Rhode Island, and Connecticut. We include controls for poverty thresholds, marital status, sex, education, race/ethnicity, and fixed effects for state and year. Our "Chapter 58 effect" is therefore identified from the interaction of state and year. We weight all regressions with the CPS weights, stratify by age group, and estimate models without imputed values. We attribute any differences between Massachusetts and the remaining New England states to the Massachusetts law. Our overall results on gains in insurance coverage are very similar to those of Long et al.

We are unaware of any published estimate of the full cost of Chapter 58, including costs that do not appear in government budgetswhich is significant in itself. For data on the cost to the Commonwealth of Massachusetts and the federal government, we rely on estimates published by the Massachusetts Taxpayers Foundation. ${ }^{12}$ For estimates of the costs imposed on the private sector, we rely on personal communications with staff from the Massachusetts Taxpayers Foundation. ${ }^{13}$

\section{Coverage Effects}

A primary objective of Chapter 58 is to expand health insurance coverage in Massachusetts, with the goal of universal coverage. In this section, we examine how many Massachusetts residents remain uninsured, and how much of the increase in coverage since 2006 can be attributed to Chapter 58 .

\section{How Many Residents Remain Uninsured?}

For 2003 through 2006, the CPS reported that the uninsured rate in Massachusetts hovered around 10 percent. Massachusetts' uninsured rate was low compared to the national average of 15 to 16 percent during that period. It was especially low relative to southwestern states, where the uninsured rate often exceeds 20 percent.

Various estimates exist of how many Massachusetts residents currently lack health insurance. The Commonwealth relies on one survey that provides an estimate of 2.6 percent

\section{We are unaware of any published estimate of the full cost of Chapter 58.}


uninsured in $2008 .^{14}$ The Census Bureau's American Community Survey provides an estimate of 4.1 percent. $^{15}$

There is controversy over whether the CPS accurately estimates Massachusetts' uninsured rate, which results from the CPS's method for dealing with households that do not answer the survey's questions about insurance status. When a respondent fails to answer a question on the CPS, the Census Bureau imputes a response for that person based on the answers of similar individuals. ${ }^{16}$ For 2008, the CPS imputes the insurance status of 1 million out of a total of 6.4 million Massachusetts residents to arrive at an uninsured estimate of 5.5 percent. ${ }^{17}$ The CPS imputes the insurance status of nearly 670,000 non-elderly adults (hereafter: "adults"), or one-sixth of the 4.1 million adult residents.

Davern et al. find that the CPS's imputation procedure tends to overstate the uninsured rate in states like Massachusetts that have relatively low uninsured rates, and that that bias may be greatest in Massachusetts. ${ }^{18}$ Working with the 1998-2000 March supplements, they estimate that the CPS's imputation procedure overstated the Massachusetts uninsured rate by 1.8 percentage points, or 13.9 percent-the largest error in any state. ${ }^{19}$ The authors suggest a rudimentary way to adjust for that bias would be to reduce Massachusetts' official uninsured rate by 13.9 percent, ${ }^{20}$ which yields an estimate of 4.7 percent.

Excluding imputed answers from the 2008 sample produces an estimate of 3.8 percent, or 205,472 uninsured residents, which is very close to the ACS estimate.

\section{“Are You Breaking the Law?"}

Research has not yet explored another potential source of bias related to the CPS's imputation procedure. Chapter 58 creates incentives for uninsured Massachusetts residents to conceal their true insurance status. Since December 31, 2007, not having health insurance coverage has had legal consequences for Massachusetts residents. Uninsured residents who accurately report their insurance status would be admitting to unlawful activity and subject to penalties. ${ }^{21}$ In addition, Chapter 58 's individual mandate may have created a social norm that uninsured residents might be reluctant to admit they are violating. If Chapter 58 induces uninsured residents to conceal their insurance status from the CPS, then that would bias the uninsured estimate downward.

Uninsured Massachusetts residents can conceal their lack of coverage from government surveys like the CPS in three ways. First, they may refuse to participate in the survey. Second, they may participate in the survey but misrepresent their coverage status. Third, they may participate in the survey but not answer the survey's health-insurance questions, whether by skipping those questions, refusing to answer them, or terminating the interview early. Nonresponse is more likely for sensitive questions like income. ${ }^{22}$ Since 2006, insurance coverage may have become a more sensitive question in Massachusetts.

Each concealment strategy would bias the CPS estimate of Massachusetts' uninsured rate in the direction of overstating the law's impact on the uninsured. If uninsured residents refuse to take the survey, they would be underrepresented in the sample. If they misrepresent their coverage status, that would cause uninsured residents to be counted as insured. If they decline to answer the insurance questions, and the CPS imputes their response, that would further increase the number of households that are counted as insured but that are actually uninsured.

We cannot observe the first or second strategies, but we can observe how often respondents do not answer the CPS's health insurance questions across states and over time. And we can compare that to nonresponse rates for other questions in the March supplements. If uninsured Massachusetts residents respond to the incentives to conceal their true insurance status, we would expect to see an increase in the rate of nonresponse to the insurance questions relative to other states and to other questions on the CPS.

We find evidence that nonresponse to the CPS's health-insurance questions increased 
Table 1

Changes in Response Rates to CPS Health Insurance and Income Questions in Massachusetts after Chapter 58

Any Imputed $\quad$ Any Imputed

Health Insurance Item Income Item
Under 18

$\mathrm{N}=24,489$

Below 150\% FPL

$\mathrm{N}=5,089$

150-300\% FPL

$\mathrm{N}=6,004$

Above 300\% FPL

$\mathrm{N}=13,396$

Age 18 to 64

$\mathrm{N}=51,582$

Below 150\% FPL

$\mathrm{N}=7,367$

150-300\% FPL

$\mathrm{N}=10,807$

Above 300\% FPL

$\mathrm{N}=33,408$
$0.003(0.015)$

$0.005(0.014)$

$0.053(0.022)$

$-0.016(0.023)$

$0.021(0.009)$

$-0.068(0.007)$

$0.021(0.016)$

$0.047(0.020)$

$0.015(0.011)$

Notes: Each estimate is a difference-in-differences estimate from a separate ordinary least squares regression. The number of observations is shown for models including all of the 2005-2008 years. All specifications include fixed effects for an individual's age, state, and year. Robust standard errors are in parentheses, corrected for clustering state-year cell. All results are weighted.

after Massachusetts enacted its mandate. In one estimation, we compare the nonresponse rates for Massachusetts residents with those of other New England states. We find no overall effect of Chapter 58 on imputations among children, but imputations among adults rose by a statistically significant 2.1 percentage points (standard error: 0.9)-a 9percent increase. The effect appears particularly strong between $150-300$ percent FPL, where initial insurance coverage was relatively low and where compliance requires residents to pay some portion of their premiums. Imputations increased by 5.3 percentage points among children (standard error: 2.2) and 4.7 percentage points among adults (standard error: 2.0) in this income stratum. There was no statistically significant change in imputations among those below 150 percent FPL. ${ }^{23}$

In short, if the entire 2.1 percentage point increase in imputations among adults was the result of them concealing their uninsured status, then the (unadjusted) uninsured rate would be 5.1 percent, instead of the 3.8 percent reported by the CPS.

These results are consistent with Chapter 58 inducing uninsured Massachusetts residents to conceal their true insurance status. Imputations rise among those between
These results are consistent with Chapter 58 inducing uninsured Massachusetts residents to conceal their true insurance status. 


The
Commonwealth's
estimate that only
2.6 percent of
residents remain
uninsured is most
likely too low.

150-300 percent FPL, who were more likely to be uninsured prior to the law's enactment, and whom the law forces to purchase health insurance with their own money. Rather than comply with the mandate, some of these "insured" individuals may instead be concealing their lack of coverage by refusing to answer the CPS's insurance-status questions. In contrast, there was no discernable change in response rates by individuals below 150 percent FPL, who receive "free" coverage and who face no penalties for not obtaining coverage.

Next, we compare nonresponse to insurance-status questions to nonresponse to the CPS's questions about income. While the response rate for the insurance-status questions fell after the enactment of Chapter 58, the response rate for income-related questions increased. Income imputations fell by 1.6 percentage points for children (standard error: 0.3 ), and among adults by 6.8 percentage points (standard error: 0.7 ). This suggests that Massachusetts residents who participated in the survey were not less forthcoming overall, just less forthcoming about health insurance coverage.

We draw a number of conclusions. First, the Commonwealth's estimate that only 2.6 percent of residents remain uninsured-the lowest estimate available-is most likely too low. More rigorous surveys all yield higher estimates. As noted above, even ignoring imputations, the CPS yields an uninsured rate of 3.8 percent. Second, we conclude that Chapter 58 has introduced a new source of bias into the CPS's estimate of Massachusetts' uninsured rate. The 3.8-percent figure is not biased upward by the CPS imputation procedure, but it may be biased downward by the incentives that Chapter 58 creates for uninsured residents to conceal their true coverage status. Whether this is a significant source of bias is unclear. As noted previously, if the entire 2.1-percentage-point rise in imputations among adults were the result of them concealing their uninsured status, then the (unadjusted) uninsured rate would be 5.1 percent. ${ }^{24}$ To the extent that uninsured residents employed either of the other concealment strategies, the true uninsured rate would be even higher and the number of newly insured residents even lower. We therefore regard 3.8 percent to be a lower-bound estimate of Massachusetts' uninsured rate. (In the same vein, we consider the below estimates of Chapter 58 's impact on coverage to be an upper-bound estimate.) Third, this source of bias may also affect other surveys, including non-government surveys.

\section{How Many Newly Insured?}

The direction of Chapter 58's effect on insurance coverage is not in dispute. The law appears to have had a significant impact on the number of insured residents. Using two-year averages, the Census Bureau estimates that Massachusetts' uninsured rate dropped from 9.8 percent in 2005-2006 to 5.4 percent in 2007-2008-a 4.4 percentage point reduction. ${ }^{25}$ But is the new law solely responsible for this increase, or did other factors contribute to it?

To isolate how many additional residents obtained coverage as a result of Chapter 58 , we control for other factors that might influence coverage levels by performing a difference-indifferences estimation using only non-imputed observations, as did Long et al. Unlike Long et al., we use other New England states as controls, and we examine 2005-2008, rather than 2004-2007.

Our results, presented in Table 2, suggest that Chapter 58 reduced the uninsured rate for children by 2 percentage points, and for adults by 6.7 percentage points. These results are similar to those of Long et al., who found an increase of 6.6 percentage points in coverage among adults. ${ }^{26}$ The effects were greatest among children between 150 percent and 300 percent of the federal poverty level (7.6 percentage points), and among adults at both below 150 percent (11 percentage points) and between 150 percent and 300 percent of the federal poverty level (14.2 percentage points). These results are unsurprising, since those groups were both the main targets of the new subsidies and subject to penalties under the individual mandate. Our difference-in-differ- 
Table 2

E ffect of C hapter 58 on Insurance C overage, Self-R eported H ealth, and In-migration

\begin{tabular}{|c|c|c|c|c|c|c|}
\hline & \multirow[b]{2}{*}{$\begin{array}{l}\text { Insurance } \\
\text { Coverage }\end{array}$} & \multirow[b]{2}{*}{$\begin{array}{l}\text { Private } \\
\text { Coverage }\end{array}$} & \multicolumn{3}{|c|}{ Self-Reported Health } & \multirow[b]{2}{*}{ In-migration } \\
\hline & & & Excellent & $\begin{array}{l}\text { Very Good } \\
\text { or B etter }\end{array}$ & $\begin{array}{l}\text { Good or } \\
\text { B etter }\end{array}$ & \\
\hline & \multicolumn{6}{|c|}{ Under 18} \\
\hline $\begin{array}{l}\text { All Income L evels } \\
N=19,454\end{array}$ & $0.020(0.005)$ & $-0.044(0.016)$ & $-0.068(0.013)$ & $-0.024(0.012)$ & $0.011(0.002)$ & \\
\hline $\begin{array}{l}\text { Under 150\% FPL } \\
N=4,153\end{array}$ & $0.027(0.016)$ & $-0.146(0.035)$ & $-0.025(0.031)$ & $0.092(0.045)$ & $0.019(0.009)$ & \\
\hline $\begin{array}{l}\text { Between } 150-300 \% \\
N=4,715\end{array}$ & $0.076(0.012)$ & $0.001(0.048)$ & $-0.161(0.033)$ & $-0.133(0.030)$ & $0.027(0.005)$ & \\
\hline $\begin{array}{l}\text { Over } \mathbf{3 0 0 \%} \\
N=10,586\end{array}$ & $-0.002(0.005)$ & $-0.013(0.005)$ & $-0.050(0.018)$ & $-0.031(0.010)$ & $0.002(0.002)$ & \\
\hline \multirow{2}{*}{$\begin{array}{l}\text { Non-movers } \\
\mathrm{N}=18,272\end{array}$} & $0.019(0.005)$ & $-0.045(0.017)$ & $-0.068(0.014)$ & $-0.031(0.012)$ & $0.009(0.003)$ & \\
\hline & \multicolumn{6}{|c|}{ Age 18 to 64} \\
\hline $\begin{array}{l}\text { All Income L evels } \\
N=41,873\end{array}$ & $0.067(0.003)$ & $0.022(0.007)$ & $-0.042(0.005)$ & $-0.013(0.006)$ & $0.008(0.004)$ & $-0.009(0.003)$ \\
\hline $\begin{array}{l}\text { Under } 150 \% \\
N=5,784\end{array}$ & $0.11(0.014)$ & $-0.062(0.024)$ & $-0.057(0.027)$ & $-0.004(0.010)$ & $0.007(0.019)$ & $-0.016(0.012)$ \\
\hline $\begin{array}{l}\text { Between } 150-300 \% \\
N=8,664\end{array}$ & $0.142(0.009)$ & $0.067(0.019)$ & $-0.045(0.014)$ & $0.040(0.020)$ & $0.007(0.014)$ & $-0.007(0.005)$ \\
\hline $\begin{array}{l}\text { Over } 300 \% \\
N=27,425\end{array}$ & $0.042(0.003)$ & $0.031(0.003)$ & $-0.034(0.089)$ & $-0.028(0.007)$ & $0.001(0.003)$ & $-0.007(0.004)$ \\
\hline $\begin{array}{l}\text { Non-movers } \\
N=40,938\end{array}$ & $0.065(0.003)$ & $0.021(0.006)$ & $-0.045(0.005)$ & $-0.016(0.006)$ & $0.010(0.003)$ & \\
\hline
\end{tabular}

Notes: Each estimate is a difference-in-differences estimate from a separate ordinary least squares regression. O bservations with imputed values for health insurance or health status were excluded. The number of observations is shown for models including all of the 2005-2008 years. All specifications include fixed effects for an individual's age, state, and year. Health results exclude the 2007 calendar year. Robust standard errors are in parentheses, corrected for clustering state-year cell. All results are weighted.

ences estimations produce a point estimate of 297,000 Massachusetts residents newly insured as of 2008 as a result of Chapter 58.

One potential implication of these findings is that Chapter 58's subsidies did more to expand coverage than the individual mandate. Since Massachusetts introduced both to roughly the same populations at roughly the same time, it is difficult to discern which intervention had the greater impact on coverage 


\section{The law appears to have achieved} more success in giving residents health insurance than shifting the population toward better health. levels. Given that we examined 2005-2008, yet obtained similar results to Long et al., one possible interpretation is that the subsidies that became available in 2007 had a greater impact on insurance coverage than the individual mandate, which only became binding as of December 31, 2007, and whose penalties dramatically increased in 2008. At a minimum, our results suggest that the subsidies had a strong impact on coverage, since the groups targeted with new subsidies saw the greatest coverage gains.

We consider 297,000 to be an optimistic estimate of Chapter 58's effect on insurance coverage, for it assumes that no uninsured Massachusetts residents concealed their insurance status. To the extent that the legal penalties or a new social norm did induce uninsured residents to conceal their coverage status, our results overstate Chapter 58's impact on coverage. A "back of the envelope" calculation suggests that if the entire 2.1-percentage-point increase in imputations among adults is the result of concealment, for example, then Chapter 58 extended coverage to only 204,000 residents.

We thus conclude that the Commonwealth's estimate of 432,000 newly insured residents $^{27}$ is too high, as it lies above the upper bound of the 95-percent confidence interval $(327,000)$ for our point estimate. The number of insured residents may have risen by 432,000 as of 2008 , but the portion that can be attributed to Chapter 58 is almost certainly smaller. The Commonwealth's official estimate appears to overstate the actual impact of the law by 45 percent.

\section{Self-Reported Health}

A primary reason to expand health insurance coverage is to improve health. An important measure of Chapter 58's impact, therefore, is whether it improved the health of Massachusetts residents. The CPS enables researchers to gauge changes in health by observing self-reported health status.

The March 2009 supplement is more use- ful for examining the effects of Chapter 58 on health than the March 2008 supplement, which would count individuals as "insured" if they obtained coverage on Dec. 31, 2007. (We would expect little effect on health from one day's worth of insurance coverage.) By observing self-reported health one year after both the subsidies and penalties took effect, the March 2009 supplement is more likely to capture any effects that Chapter 58 would have on health status. Of course, we would not expect data covering 1.5 years of the experience with Chapter 58 to capture the full effect of the expanded health insurance coverage on health outcomes, but it is reasonable to assume that some improvement should be visible. Researchers such as Janet Currie and Jonathan Gruber find that Medicaid expansions affect health outcomes of infants and children in a short period of time. ${ }^{28}$

We again perform a difference-in-differences estimation using other New England states as controls. Since the law had been only partially implemented in 2007, we exclude data from 2007 and compare selfreported health in 2005-2006 to 2008 . $^{29}$

We find mixed effects on self-reported health after 2006. Table 2 shows improvements in good (or better) health, but declines in excellent and very good (or better) health. For example, among children, excellent health fell by 6.8 percentage points but good (or better) health increased by 1.1 percentage points. Where the coefficients are statistically significant, those countervailing effects are similar for adults and for most income subgroups. One exception is children under 150 percent FPL: the reduction in excellent health is not statistically significant, but the improvements in both good (or better) and very good (or better) health are statistically significant. Another exception is that adults between 150-300 percent FPL saw a statistically significant increase in very good (or better) health. Yet the same group also saw a drop in excellent health and no discernable change in good (or better) health.

Overall, it appears that the distribution of health status compressed, but did not neces- 
sarily improve, in response to Chapter 58 . To date, the law appears to have achieved more success in giving residents health insurance than shifting the population toward better health.

\section{Evidence of Crowd-Out}

One concern that arises when expanding government assistance is the tendency for government subsidies to substitute for, or "crowd-out," private effort. Crowd-out can occur because those newly eligible for government health insurance subsidies drop their private coverage or because employers cease offering coverage to eligible groups. ${ }^{30}$ Previous studies of Chapter 58 have found no evidence of crowd-out, in that both public and private coverage expanded since $2006 .{ }^{31}$

Using a difference-in-differences estimation, we find that while coverage generally expanded for children and adults, private insurance coverage fell among certain income groups in Massachusetts relative to other New England states. Table 2 shows that private coverage fell by 4.4 percentage points among children, perhaps driven by a 14.6-percentagepoint drop among children below 150 percent of the federal poverty level. Private coverage rose for adults overall, but fell by 6.2 percentage points among adults below 150 percent of poverty level. Again, this result is unsurprising, as Massachusetts targeted government programs principally at those groups.

We consider this to be evidence of substantial crowd-out among the poor, as well as a conservative measure of overall crowd-out, given that we cannot observe the extent to which public subsidies offered to those who purchase private insurance merely substituted for private dollars.

\section{In-migration}

Another potential effect of Chapter 58 is that its taxes and subsidies may affect Massachusetts' attractiveness as a place to live. The law affects different individuals differently; individuals likely to receive net subsidies may find the Commonwealth a more attractive place to relocate, while those likely to face net taxes would find it less attractive. The March supplement to the CPS measures in-migration for each state, which offers one tool to evaluate any effects that Chapter 58 may have on people's decisions to relocate to Massachusetts.

From 2005 to 2008, in-migration into other New England states fell from 2.4 percent to 2.2 percent. Migration into Massachusetts fell from 1.6 percent to 1.2 percent (data not shown.) A "back of the envelope" differencein-differences estimate thus suggests that Massachusetts became a less attractive place to relocate after the enactment of Chapter 58.

The statistically significant regressionadjusted estimates are broadly consistent with the unadjusted data. Relative to other New England states, Massachusetts saw a 0.61 percentage point decline in in-migration postChapter 58 for the sample as a whole. For adults, the decline was 0.87 percentage points. For adults aged 18 to 29 , in-migration fell by a sizable 2.8 percentage points-more than four times the magnitude for the entire sample, and a 62-percent drop from baseline in-migration among young adults (data not shown). Since the young tend to have much higher uninsurance rates, and the combination of the individual mandate and Massachusetts' strict community-rating price controls imposes greater implicit taxes on young adults than others, ${ }^{32}$ a reasonable interpretation of these results is that those whom Chapter 58 would most adversely affect voted with their feet and avoided Massachusetts.

\section{Is It Worth the Cost?}

Chapter 58's benefits must be weighed against the costs it imposes. ${ }^{33}$ Premiums appear to have declined in the non-group market, ${ }^{34}$ which accounts for 4 percent of private health insurance in Massachusetts. ${ }^{35}$ It is unclear, however, whether and to what extent
Those whom Chapter 58 would most adversely affect voted with their feet and avoided Massachusetts. 
We estimate total new spending to be more than $\$ 1$ billion in 2008, or 57 percent more than the Massachusetts Taxpayers Foundation formal estimates suggest. that was the result of greater efficiency or cost-shifting to the (larger) small-employer market when Chapter 58 merged the two. Whatever the case, premiums in the other 96 percent of the market moved in the opposite direction. One study found that public and private spending on health insurance have accelerated. ${ }^{36}$ Another found that premiums for employer-sponsored insurance in Massachusetts grew 21-46 percent faster than the national average over roughly the period studied here. ${ }^{37}$

The full cost of Chapter 58 includes not only new state and federal government spending, but also any new private-sector spending undertaken to comply with the law's unfunded mandates. The law uses the Commonwealth's sovereign power to require employers and individuals to purchase health insurance for previously uninsured residents. It even requires some residents who already were insured to purchase additional coverage to comply with the individual mandate's standard for "minimum creditable coverage."

We are unaware of any effort to tally all of the costs imposed by Chapter 58. The Massachusetts Taxpayers Foundation has formally estimated the cost to the state and federal governments and declared the cost of Chapter 58 to be "modest," based on the costs to the state government. Working with informal estimates provided by the Massachusetts Taxpayers Foundation, we reach a "back of the envelope" estimate that new state and federal spending amounts to just two-thirds of all new spending under Chapter 58, the remaining third being additional private-sector spending to comply with the individual and employer mandates. We estimate the total new spending to be more than $\$ 1$ billion in 2008, or 57 percent more than the Massachusetts Taxpayers Foundation formal estimates suggest.

We consider this to be a conservative estimate of Chapter 58's cost for a number of reasons. This estimate includes only new federal spending, state spending, and new spending by previously uninsured residents. It does not include any new spending that previously insured Massachusetts residents must undertake to comply with the individual mandate, which required many residents to purchase coverage with less cost-sharing and more covered services than they had. In addition, there is a strong argument that the true cost of the individual and employer mandates includes not just the new spending mandated by the law, but all mandated spending, including the health insurance premiums that residents had been paying voluntarily. In its official cost estimate of the Clinton administration's health plan, the Congressional Budget Office included all mandatory premiums in the federal budget. ${ }^{38}$ Viewed from that perspective, our estimate dramatically understates the cost of Chapter 58.

\section{Is It Cost-Effective?}

Even less attention has been paid to whether Chapter 58 was the lowest-cost means of achieving whatever outcomes the law has produced. We are aware of no effort to ascertain whether the benefits of Chapter 58-in terms of better health, better access to care, financial security, etc.-could have been obtained at a lower cost.

This appears to be a hole in both the economic literature and the priorities of policymakers. In 2004, Helen Levy and David Meltzer wrote, "There is no evidence at this time that money aimed at improving health would be better spent on expanding insurance coverage than on . . other possibilities. ${ }^{39}$ Levy and Meltzer reaffirmed that conclusion in 2008:

The central question of how health insurance affects health, for whom it matters, and how much, remains largely unanswered at the level of detail needed to inform policy decisions. ... Understanding the magnitude of health benefits associated with insurance is not just an academic exercise ..., it is crucial to ensuring that the benefits of a given 
amount of public spending on health are maximized. ${ }^{40}$

Judicious policymaking is unlikely in the absence of that information.

\section{Conclusion}

Our analysis of CPS data for 2008 shows that Massachusetts' health law has had a smaller impact on insurance coverage levels and a much higher cost than supporters claim. Gains in coverage have been overstated by nearly 50 percent, while costs have been understated by at least one-third, and likely more. The law has done little to improve overall self-reported health, though it does appear to have crowded out private health insurance and made Massachusetts a less attractive place to relocate, particularly for young people.

These findings hold lessons for the legislation moving through Congress, which largely resembles the Massachusetts law. As in Massachusetts, there has been no effort to estimate the full cost of the legislation-that is, including the mandates it would impose on individuals and employers. The costs of that legislation are therefore far greater than members of Congress and voters believe, while the benefits may be smaller than the conventional wisdom about Massachusetts suggests.

\section{Notes}

1. This description of Chapter 58 draws from Sharon K. Long, "On the Road to Universal Coverage: Impacts of Reform in Massachusetts at One Year," Health Affairs Web Exclusive (June 3, 2008), p. w271, http://bit.ly/7kTVcG.

2. See Commonwealth of Massachusetts Department of Revenue, "DOR Issues Updated Report on Insurance Mandate Compliance in 2007 and Draft Penalty Guidelines for the Uninsured in 2009," December 22, 2008, http://bit.ly/67kEha.

3. Economists broadly agree that "employer contributions" to employee health benefits are not employer contributions at all, but are deducted from workers' wages. See Michael A. Morrissey and John Cawley, "Health Economists' Views of Health Policy," Journal of Health, Politics, Policy, and Law 33, no. 4 (August 2008): 712.

4. Romney emphasized, "All Massachusetts citizens will have health insurance." Mitt Romney, "Health Care for Everyone? We've Found a Way," Wall Street Journal, April 11, 2006, http://bit.ly/5d fgBI.

5. White House Office of the Press Secretary, "Remarks by the President to a Joint Session of Congress on Health Care," September 9, 2009, http: //bit.ly/5OZNAs.

6. M. Davern et al., "Are the CPS Uninsurance Estimates Too High? An Examination of Imputation," HSR:Health Services Research 42, no. 5 (October 2007): 2038-2055.

7. The Census Bureau did add a health insurance verification question in the March 2000 supplement.

8. Long, "On the Road to Universal Coverage."

9. Sharon K. Long, Allison Cook, and Karen Stockley, "Health Insurance Coverage in Massachusetts: Estimates from the 2008 Massachusetts Health Insurance Survey," Division of Health Care Finance and Policy, Commonwealth of Massachusetts Office of Health and Human Services, December 19, 2008, p. 2, http://bit.ly/7ll8wk.

10. See U.S. Bureau of the Census, Current Population Survey, http://www.bls.census.gov/ cps_ftp.html.

11. Sharon K. Long et al., "Another Look at the Impacts of Health in Massachusetts: Evidence Using New Data and a Stronger Model," American Economic Review: Papers and Proceedings 99, no. 2 (May 2009): 508-11, http://bit.ly/5VOWKa.

12. Alan G. Raymond, "Massachusetts Health: The Myth of Uncontrolled Costs," Massachusetts Taxpayers Foundation, May 2009, http://bit.ly/ 4WUmTb.

13. Personal correspondence with Massachusetts Taxpayers Foundation president Michael J. Widmer, July 20, 2009, available on request.

14. Commonwealth of Massachusetts Health Connector, "Health Facts and Figures," August 2009, p. 4, http://bit.ly/4Tza1G.

15. Joanna Turner et al., "A Preliminary Evaluation of Health Insurance Coverage in the 2008 American 
Community Survey," U.S. Bureau of the Census, September 22, 2009, p. 9, http://bit.ly/4GxDQ1.

16. Davern et al., "Are the CPS Uninsurance Estimates Too High?”

17. U.S. Bureau of the Census, "Historical Health Insurance Tables: Table HIA-4. Health Insurance Coverage Status and Type of Coverage by StateAll Persons: 1999 to 2008," September 22, 2009, http://bit.ly/7jG4ND. There is a scholarly consensus that although the March supplement to the CPS attempts to capture the number of respondents who were uninsured for the whole of the previous year, it actually captures the number of respondents who were uninsured on the day they took the survey, which tends to be larger than the number actually uninsured for all of the previous year. See, for example, U.S. Congressional Budget Office, "How Many People Lack Health Insurance and For How Long?” May 2003, http://bit.ly/6u WfUh. The CPS can nevertheless capture trends in health insurance coverage.

18. "Th[e] combination of having a relatively low uninsurance rate and having a relatively high number of imputations makes Massachusetts more susceptible to the bias." M. Davern et al., "Missing the Mark? Possible Imputation Bias in the Current Populations Survey's State Income and Health Insurance Coverage Estimates," Journal of Official Statistics 20, no. 3 (2004): 544.

19. M. Davern et al., "Missing the Mark?"

20. Ibid., p. 546.

21. A small number of Massachusetts residents are exempt from the individual mandate.

22. Davern et al., "Missing the Mark?,” pp. 519-49.

23. Our data reveal that imputed values for health insurance were unusually high in 2005 relative to the 2006-2008 period. More than 30 percent of individuals had at least one CPS health insurance item imputed in 2005, compared with 13.4-17.6 percent in the subsequent years. On the other hand, imputed values for income vary between 29.6 and 31.1 percent over the full time period. Due to the concern about the high relative rate of imputations in 2005, we re-ran our regressions excluding the 2005 calendar year. Our assessment of the impact of the Massachusetts law on the incentive to not report, if anything, is strengthened by excluding 2005.

24. This figure ignores any increase in imputations among children, which is statistically significant in the 150-300 percent FPL stratum, and therefore underestimates the potential bias from induced nonresponse.

25. This is statistically significant at a 90-percent confidence interval. U.S. Bureau of the Census, "Number and Percentage of People without Health Insurance Coverage by State Using 2- and 3-Year Averages: 2005-2006 and 2007-2008," http://bit.ly /7gcazN.

26. See Sharon K. Long et al., "Another Look at the Impacts of Health in Massachusetts: Evidence Using New Data and a Stronger Model," American Economic Review: Papers and Proceedings 99, no. 2 (May 2009): 511, Table 1, http://bit.ly/5VOWKa.

\section{Raymond.}

28. See Jonathan Gruber and Janet Currie, "Health Insurance Eligibility, Utilization of Medical Care, and Child Health," Quarterly Journal of Economics 111, no. 2 (May 1996): 431-66, http://bit.ly/6M 6iI8; and Jonathan Gruber and Janet Currie, "Saving Babies: The Efficacy and Cost of Recent Expansions of Medicaid Eligibility for Pregnant Women," Journal of Political Economy 104, no. 6 (January 1997): 1263-96, http://bit.ly/8LRWQ9. Presumably, the response of an objective health measure like infant mortality to policy changes should be more inelastic than the response of selfreported health. The main shortcoming of using self-reported health as a health outcome is how self-reported health maps onto more objective measures of health.

29. Including 2007 data reduces the improvements in good (or better) health, yet still shows self-reported health compressing (data not shown).

30. For an overview of the literature on crowd-out, see Jonathan Gruber and Kosali Simon, "Crowdout 10 Years Later: Have Recent Public Insurance Expansions Crowded out Private Health Insurance?” Journal of Health Economics 27, no. 2 (March 2008): 201-17, http://bit.ly/74UzPy.

31. See Sharon K. Long, "On the Road to Universal Coverage: Impacts of Reform in Massachusetts at One Year Long," Health Affairs Web Exclusive (June 3, 2008): w271, http://bit.ly/7kTVcG; and Sharon $\mathrm{K}$. Long et al., "Another Look at the Impacts of Health in Massachusetts: Evidence Using New Data and a Stronger Model," American Economic Review: Papers and Proceedings 99, no. 2 (May 2009): 508-11, http://bit.ly/5VOWKa.

32. See Aaron Yelowitz, "ObamaCare: A Bad Deal for Young Adults," Cato Institute Briefing Paper no. 115, November 5, 2009, http://bit.ly/7qUTXm.

33. Some observers maintain that cost control was 
not an objective of Chapter 58, in spite of Governor Romney's promises of lower health care costs. See, for example, Michelle Andrews, "Health Care: Stop Focusing on the Cost," CBS Moneywatch, August 6, 2009, http://bit.ly/4EfSN0.

34. U.S. Census Bureau, "Table HI05. Health Insurance Coverage Status and Type of Coverage by State and Age for All People: 2008," Current Population Survey, 2009 Annual Social and Economic Supplement, Page Last Modified: September 11, 2009, http://bit.ly/8Qh1LW.

35. Ibid.

36. Robert Seifert and Paul Swoboda, "Shared Responsibility: Government, Business, and Individuals: Who Pays What for Health?" Blue Cross Blue Shield of Massachusetts Foundation, March 2009, http://bit.ly/4X3NaI.
37. Cathy Schoen, Jennifer L. Nicholson, and Sheila D. Rustgi, "Paying the Price: How Health Insurance Premiums Are Eating up Middle-Class Incomes," The Commonwealth Fund, August 2009, p. 8, http://bit.ly/91cTbe.

38. See U.S. Congressional Budget Office, "An Analysis of the Administration's Health Proposal," February 1994, http://bit.ly/5VxkUP.

39. Helen Levy and David Meltzer, "What Do We Really Know about Whether Health Insurance Affects Health?" in Health Policy and the Uninsured, ed. Catherine G. McLaughlin (Washington: Urban Institute Press, 2004), p. 201.

40. Helen Levy and David Meltzer, "The Impact of Health Insurance on Health," Annual Review of Public Health 29 (April 2008): 399-409, http://bit. ly/4ytmhz.

\section{STUDIES IN THE POLICY ANALYSIS SERIES}

656. Obama's Prescription for Low-Wage Workers High Implicit Taxes, Higher Premiums by Michael F. Cannon (January 13, 2010)

655. Three Decades of Politics and Failed Policies at HUD by Tad DeHaven (November 23, 2009)

654. Bending the Productivity Curve: Why America Leads the World in Medical Innovation by Glen Whitman and Raymond Raad (November 18, 2009)

653. The Myth of the Compact City: Why Compact Development Is Not the Way to Reduce Carbon Dioxide Emissions by Randal O’Toole (November 18, 2009)

652. Attack of the Utility Monsters: The New Threats to Free Speech by Jason Kuznicki (November 16, 2009)

651. Fairness 2.0: Media Content Regulation in the 21st Century by Robert Corn-Revere (November 10, 2009)

650. Yes, Mr President: A Free Market Can Fix Health Care by Michael F. Cannon (October 21, 2009)

649. Somalia, Redux: A More Hands-Off Approach by David Axe (October 12, 2009) 
648. Would a Stricter Fed Policy and Financial Regulation Have Averted the Financial Crisis? by Jagadeesh Gokhale and Peter Van Doren (October 8, 2009)

647. Why Sustainability Standards for Biofuel Production Make Little Economic Sense by Harry de Gorter and David R. Just (October 7, 2009)

646. How Urban Planners Caused the Housing Bubble by Randal O'Toole (October 1, 2009)

645. Vallejo Con Dios: Why Public Sector Unionism Is a Bad Deal for Taxpayers and Representative Government by Don Bellante, David Denholm, and Ivan Osorio (September 28, 2009)

644. Getting What You Paid For-Paying For What You Get: Proposals for the Next Transportation Reauthorization by Randal O’Toole (September 15, 2009)

643. Halfway to Where? Answering the Key Questions of Health Care Reform by Michael Tanner (September 9, 2009)

642. Fannie Med? Why a "Public Option" Is Hazardous to Your Health by Michael F. Cannon (July 27, 2009)

641. The Poverty of Preschool Promises: Saving Children and Money with the Early Education Tax Credit by Adam B. Schaeffer (August 3, 2009)

640. Thinking Clearly about Economic Inequality by Will Wilkinson (July 14, 2009)

639. Broadcast Localism and the Lessons of the Fairness Doctrine by John Samples (May 27, 2009)

638. Obamacare to Come: Seven Bad Ideas for Health Care Reform by Michael Tanner (May 21, 2009)

637. Bright Lines and Bailouts: To Bail or Not To Bail, That Is the Question by Vern McKinley and Gary Gegenheimer (April 21, 2009)

636. Pakistan and the Future of U.S. Policy by Malou Innocent (April 13, 2009)

635. NATO at 60: A Hollow Alliance by Ted Galen Carpenter (March 30, 2009)

634. Financial Crisis and Public Policy by Jagadeesh Gokhale (March 23, 2009)

633. Health-Status Insurance: How Markets Can Provide Health Security by John H. Cochrane (February 18, 2009) 
632. A Better Way to Generate and Use Comparative-Effectiveness Research by Michael F. Cannon (February 6, 2009)

631. Troubled Neighbor: Mexico's Drug Violence Poses a Threat to the United States by Ted Galen Carpenter (February 2, 2009)

630. A Matter of Trust: Why Congress Should Turn Federal Lands into Fiduciary Trusts by Randal O’Toole (January 15, 2009)

629. Unbearable Burden? Living and Paying Student Loans as a First-Year Teacher by Neal McCluskey (December 15, 2008)

628. The Case against Government Intervention in Energy Markets: Revisited Once Again by Richard L. Gordon (December 1, 2008)

627. A Federal Renewable Electricity Requirement: What's Not to Like? by Robert J. Michaels (November 13, 2008)

626. The Durable Internet: Preserving Network Neutrality without Regulation by Timothy B. Lee (November 12, 2008)

625. High-Speed Rail: The Wrong Road for America by Randal O’Toole (October 31, 2008)

624. Fiscal Policy Report Card on America's Governors: 2008 by Chris Edwards (October 20, 2008)

623. Two Kinds of Change: Comparing the Candidates on Foreign Policy by Justin Logan (October 14, 2008)

622. A Critique of the National Popular Vote Plan for Electing the President by John Samples (October 13, 2008)

621. Medical Licensing: An Obstacle to Affordable, Quality Care by Shirley Svorny (September 17, 2008)

620. Markets vs. Monopolies in Education: A Global Review of the Evidence by Andrew J. Coulson (September 10, 2008)

619. Executive Pay: Regulation vs. Market Competition by Ira T. Kay and Steven Van Putten (September 10, 2008)

618. The Fiscal Impact of a Large-Scale Education Tax Credit Program by Andrew J. Coulson with a Technical Appendix by Anca M. Cotet (July 1, 2008) 
617. Roadmap to Gridlock: The Failure of Long-Range Metropolitan Transportation Planning by Randal O’Toole (May 27, 2008)

616. Dismal Science: The Shortcomings of U.S. School Choice Research and How to Address Them by John Merrifield (April 16, 2008)

615. Does Rail Transit Save Energy or Reduce Greenhouse Gas Emissions? by Randal O’Toole (April 14, 2008)

614. Organ Sales and Moral Travails: Lessons from the Living Kidney Vendor Program in Iran by Benjamin E. Hippen (March 20, 2008)

613. The Grass Is Not Always Greener: A Look at National Health Care Systems Around the World by Michael Tanner (March 18, 2008)

612. Electronic Employment Eligibility Verification: Franz Kafka's Solution to Illegal Immigration by Jim Harper (March 5, 2008)

611. Parting with Illusions: Developing a Realistic Approach to Relations with Russia by Nikolas Gvosdev (February 29, 2008)

610. Learning the Right Lessons from Iraq by Benjamin H. Friedman, Harvey M. Sapolsky, and Christopher Preble (February 13, 2008)

609. What to Do about Climate Change by Indur M. Goklany (February 5, 2008)

608. Cracks in the Foundation: NATO's New Troubles by Stanley Kober (January 15, 2008)

607. The Connection between Wage Growth and Social Security's Financial Condition by Jagadeesh Gokhale (December 10, 2007)

606. The Planning Tax: The Case against Regional Growth-Management Planning by Randal O’Toole (December 6, 2007)

605. The Public Education Tax Credit by Adam B. Schaeffer (December 5, 2007)

604. A Gift of Life Deserves Compensation: How to Increase Living Kidney Donation with Realistic Incentives by Arthur J. Matas (November 7, 2007)

603. What Can the United States Learn from the Nordic Model? by Daniel J. Mitchell (November 5, 2007) 